Nadwa | Jurnal Pendidikan Islam

Vol. 9, Nomor 2, Oktober 2015

\title{
Kurikulum Madrasah: \\ Studi Perbandingan Madrasah Di Asia
}

\author{
Muhammad Nasir \\ IAIN Samarinda, Indonesia \\ Email: ozan99@yahoo.com
}

\begin{abstract}
Madrasah is one of the oldest Islamic education institution. At first, the school only develop curriculum with Islamic competences are the main objectives .. Madrasah today has been integrating the Islamic knowledge and sciences. Several countries in Asia both predominantly Muslim and minority seems that they have developed madrasa education institutions as one attractive option for people. Every country has the madrassa who coined according to the characteristics typical of a country, There are significant similarities, all madrassas in various countries have a curriculum that combines religious education in the form of Aquran, Hadith, Fiqh, Tawhid, historical and moral theology and general education based on demands of each country
\end{abstract}

Keywords: madrasas, the curriculum, asia

\begin{abstract}
Abstrak
Madrasah merupakan salah lembaga pendidikan Islam tertua. Pada mulanya, madrasah hanya mengembangan kurikulum dengan kompetensi keislaman yang menjadi tujuan utama. Madrasah masa kini telah memadukan antara ilmu-ilmu kesilaman, ilmu-ilmu umum dan teknoogi. Beberapa negara di Asia baik yang penduduknya mayoritas muslim maupun yang minoritas telah memgembangkan lembaga pendidikan madrasah sebagai salah satu pilihan menarik buat masyarakatnya. Setiap negara memiliki madrasah yang memiiki ciri khas sesuai dengan karakteristik negara di mana madrasah itu berada, Terdapat persamaan yang penting, semua madrasah di berbagai negara memiliki kurikulum yang memadukan antara pendidikan keagamaan berupa Aquran, Hadis, Fiqh, Tauhid, sejarah dan akidah akhlak dan pendidian umum yang menjadi tuntutan negara masingmasing
\end{abstract}

Kata Kunci: madrasah, kurikulum, asia 


\section{Pendahuluan}

Kajian tentang madrasah dalam dunia Islam, merupakan hal yang tidak pernah ada akhirnya. Bahkan beberapa tahun terakhir ini, madrasah mencuri perhatian dunia Barat yang ditandai dengan meningkatnya ketertarikan Barat termasuk Amerika Serikat untuk mengkaji eksistensi madrasah pasca peristiwa 11 september 2001 di USA. Setelah tragedi 11 September di USA tersebut, beberapa tulisan di media cetak dan elektronik mengindettikan madrasah dengan "dens of terror", "Jihad Universities" dan "Jihad factories" atau istilah lain seperti "militansi Islam, radikalis dan anti Amerika. Negara-negara muslim sebagai basis madrasah menjadi sorotan utama pasca peristiwa itu. Di antara Negara-negara muslim yang dimaksud adalah Pakistan, Bangladesh, bahkan Indonesia.

Terlepas dari tuduhan di atas, sebuah kenyataan yang harus diakui bahwa institusi madrasah di berbagai negara muslim memang merupakan institusi pendidikan Islam yang mengalami perkembangan sesuai dengan kebutuhan dan perubahan yang terjadi di dalam masyarakatnya ${ }^{1}$. Hal ini ditandai dengan dua hal utama penting yaitu;

Pertama, Perkembangan ilmu. Madrasah dalam perkembangannya selalu menyesuaikan dengan perkembangan ilmu pengetahuan. Pada masa awal, ilmu-ilmu yang diajarkan di madrasah sangat dominan al- ilm al-naqliyah yaitu ilmu yang berkaitan dengan Alquran seperti tafsir, qiraat, hadis, ushul fiqh dan lain-lain. Dalam perkembangan berikutnya, terutama pada masa khilafah Abbasiyah, madrasah telah mengajarkan ilm al-'Aqliiyah seperti filsafat, matematika, kedokteran dan lain-lain.

Kedua, perkembangan kebutuhan. Pada masa awal, kebutuhan utama umat Islam adalah dakwah Islam, maka sasaran madrasah lebih mengutamakan kepada pendidikan orang dewasa. Ketika penganut Islam semakin banyak, maka sasaran institusi inipun disesuaikan. $^{2}$

Dalam makalah ini, penulis mengeksplorasi dinamika sistem madrasah terutama kurikulumnya dengan melakukan perbandingan di antara beberapa negara muslim Asia dan Afrika.

${ }^{1}$ Nashruddin, Wakhid, Teaching English as A Foreign Language at Madrasah Ibtidaiyyah: Facts and Challenges. dalam Jurnal Dinamika Ilmu, Vol. 15 No 1,2015

${ }^{2}$ Suwito ...., 2005,hlm. 201-202 


\section{Insitusi Pendidikan Islam Pra Madrasah}

Pengungkapan institusi pendidikan Islam pra-madrasah menjadi penting untuk menciptakan pemahaman tentang madrasah secara holistik. Bagaimanapun, sejarah berdiri madrasah merupakan transformasi dari institusi sebelumnya. Berdirinya institusi pendidikan Islam, termasuk madrasah merupakan alat dalam menyebarkan ajaran agama Islam. Oleh karena itu, tidak berlebihan jika dikatakan bahwa madrasah muncul sejalan dengan perjalanan perkembangan Islam sejak masa Rasulullah hingga saat ini.

Institusi pertama yang digunakan sebagai tempat kegiatan belajar membaca, menulis, dan menghafal Alquran sebelum berdirinya madrasah adalah dar al-arqam. (rumah sahabat Nabi yang letaknya di luar Mekkah). Setelah Hijrah ke Madinah, kegiatan pendidikan dipusatkan di masjid Nabawi. Menurut Syalabi dan Mehdi, selain masjid, beberapa istilah yang digunakan dalam sistem pendidikan pada periode pertama dan kedua adalah maktab, sekolah istana, sekolah kedai buku, shuffah, halaqah, khan, ribath, rumah sakit, toko buku, perpustakaan dan lain-lain. ${ }^{3}$

Hasan Abd al-'Ali menyebutkan lima sistem pendidikan ( $m a-$ daris al-tarbiyah) dengan klasifikasi sebagai berikut: 1)sistem pendidikan mu'tazilah yang menggunakan al-masajid, al-maktabat, hawanit, al-warraqin, dan al-muntadiyat sebagai institusi pendidikannya. 2) Sistem pendidikan Ikhwan al-shafa yang menggunakan dar al-hikmah, al-masajid dan pertemuan rahasia sebagai institusi pendidikanya. 3) Sistem pendidikan bercorak fiqh yang menggunakan al-katatib. Al-madaris dan al-masajid sebagai institusi pendidikannya. 4) Sistem pendidikan bercorak filsafat yang menggunakan dar al-hikmah, al-muntadiyat, hawani dan warraqin sebagai institusinya. 5) Sistem pendidikan yang bercorak tasawuf yang menggunakan al-zawa, al-ribat, al- masaiddan halaqat aldzikir sebagai institusi pendidikannya. ${ }^{4}$

Dari berbagai institusi di atas, Ahmad Syalabi dalam bukunya yang berjudul Al-tarbiyah Islamiyah, Nazumaha, Falsafatuha wa Tarikhuha membagi menjadi dua kelompok yaitu institusi sebelum madrasah dan institusi sesudah madrasah. Madrasah yang dimaksud

\footnotetext{
${ }^{3}$ Suwito..., hlm. 212-213.

${ }^{4}$ Maksum..., hlm. : 51
} 
di sini adalah madrasah yang didirikan oleh Nizam al-Mulk pada tahun $456 \mathrm{H}^{5}$

\section{Pengertian Dan Sejarah Berdiri Institusi Madrasah}

Kata madrasah berasal dari "darasa" yang berarti belajar. Kata ini kemudian di-tashrif dalam bentuk isim makan (kata yang menunjuk pada tempat) menjadi madrasah yang berarti tempat belajar baik bagi murid yang level (TK, SD/MI, SMP/MTS/SMU/MA ) rendah maupun level tinggi (Perguruan Tinggi). Makna lain dari "darasa" adalah terhapus, hilang bekasnya, menjadikan usang, melatih dan mempelajari. ${ }^{6}$ ). Berdasarkan arti madrasah tersebut, maka diketahui bahwa istilah madrasah merupakan tempat untuk mencerdaskan para peserta didik, menghilangkan ketidaktahuan, atau memberantas kebodohan mereka serta melatih keterampilan mereka sesuai bakat, minat dan kemampuannya. Madrasah juga tidak hanya diartikan sebagai sekolah dalam arti sempit, tetapi juga bisa dimaknai dengan rumah, istana, kuttab, masjid, perpustakaan, surau dan tempat-tempat lainnya. Bahkan seorang ibu dapat dikategorikan sebagai al-madrasah al"ula.(madrasah pemula). ${ }^{7}$

Secara historis menurut Al-Maqrizi, madrasah tidak dikenal pada masa sahabat dan tabi'in. Ia diciptakan sesudah 400 tahun setelah Hijriyah. Dalam perkembangannya, pemakaian istilah "madrasah" secara definitive baru muncul pada abad- $11 \mathrm{M}$. Penjelmaan istilah "madrasah" merupakan transformasi dari masjid ke madrasah. Ada beberapa teori yang berkembang seputar seputar transformasi ini, di antaranya; pandangan Ahmad Syalabi menjelaskan bahwa madrasah merupakan transformasi institusi pendidikan Islam dari masid ke madrasah terjadi secara langsung sebagai konsekwensi logis dari semakin ramainya kegiatan yang dilaksanakan di masjid yang tidak hanya dalam kegiatan ibadah mahdhah, tetapi juga dalam bentuk ibadah ijetima 'iyah. Sementara itu, meskipun ada yang beranggapan bahwa peralihan dari masjid ke madrasah itu terjadi secara tidak langsung. ${ }^{8}$

\footnotetext{
${ }^{5}$ Suwito..., hlm: 200-201.

${ }^{6}$ Luis Ma'luf...,1986, hlm. 187

${ }^{7}$ Al-Hasyimi ..., 1985, hlm. 200

${ }^{8}$ Ahmad Syalabi..., 1954, hlm. 257-259
} 
Madrasah dikenal pertama kali didirikan pada Tahun 1005 oleh dinasti Fatimiyah di Mesir. Saat ini, madrasah telah memiliki perpustakaan, guru dengan materi ajar yang berbeda dan siswa dengan fasilitas belajar yang tersedia. Pandangan lain menyebutkan bahwa Dinasti Saljuk yang dikenal dengan nidzamul mulk bin alThusi telah mendirikan pertama kali organisasi madrasah pada tahun 1067 M dengan dua type yaitu 1) Scholastic yang dibentuk untuk melahirkan pemimpin spiritual dan 2) Eartly Knowledge yang dibentuk untuk menghasilkan pegawai pemerintahan. Lebih jauh, Nidzamul Mulk juga mendirikan madrasah di luar kerajaan untuk menghasilkan ahli dalam berbagai bidang seperti sains, filsafat, administrasi publik dan pemerintahan. Dengan jasa ini, beliau dianggap sebagai "bapak sistem pendidikan masyarakata Islam". ${ }^{9}$

Terjadi perbedaan pendapat tentang madrasah yang pertama berdiri di dunia Islam. Di antara pandangan tersebut adalah ; 1) madrasah sebagai lembaga pendidikan formal telah dikenal adanya "Madrasah Nidzamiyah" di Bagdad yang didirikan oleh Nidzam alMuluk seorang wazir dari dinasti Saljuk pada awal abad ke-11 M. atau Tahun 457 H., 2) menurut al-Jumbulati bahwa sebelum abad ke-10, madrasah yang pertama berdiri adalah madrasah al-Baihaqiah di kota Nisabur yang didirikan oleh Abu Hasan al-Baihaqi (w. 414 H). 3) Menurut Richard Bulliet bahwa madrasah Miyan Dahiyah di Nisapur berdiri dua abad sebelum berdirinya madrasah Nizyamiah di Bagdad yang mengajarkan fiqh malikiyah. ${ }^{10}$

Terlepas dari perbedaan pendapat tentang madrasah yang pertama berdiri di dunia Islam, namun madrasah Nidzam al-Muluk adalah madrasah yang paling polpuler di kalangan ahli sejarah dan masyarakat Islam. Menurut Mehdi, meskipun madrasah Nidzam alMuluk bukan sebagai madrasah yang pertama didirikan, namun madrasah ini memiliki spirit ilmu pengetahun yang tinggi, baik dari tujuan politik dan agama. Dan yang paling menarik adalah proses pendirian madrasah ini mendapat dukungan dari berbagai pihak yaitu pemerintah, ulama-ulama, dan masyarakat. Hal ini menunjukkan bahwa madrasah Nidzamiyah ini didirikan atas kemauan dan keinginan bersama bukan keinginan sepihak.

${ }^{9}$ Uzma ..., 2003.hlm. 4-5
${ }^{10}$ Suwito ...,hlm. 214-215 


\section{Kurikulum Madrasah Di Beberapa Negera Asia Madrasah di Indonesia}

Indonesia sebagai negara yang penduduknya mayoritas beragama Islam, memiliki beberapa institusi pendidikan Islam baik pada awal mula masuk dan berkembangnya agama Islam maupun pada masa modern. Pada awal mula masuk dan berkembangnya agama Islam, pendidikan Islam di Indonesia masih berlangsung secara informal dengan beberapa institusi pendidikan Islam seperti masjid, pesantren, meunasah, rangkang, dayah dan surau. Sementara pada masa berikutnya, telah muncul institusi baru seperti madrasah, sekolah dinas dan Pendidikan Tinggi Islam

Institusi madrasah sendiri di Indonesia baru popular setelah awal abad keduapuluh. Kehadiran institusi ini (madrasah) sebagai lembaga pendidikan Islam dilatarbelakangi oleh munculnya semangat pembaruan pendidikan Islam di Indonesia. Madrasah sebagai lembaga pendidikan yang muncul setelah pesantren dan sekolah mengadopsi system pesantren dan sekolah. Madrasah di Indonesia memiliki jenjang yang sama dengan sekolah umum yaitu Madrasah Ibtidaiyah dengan lama belajar 6 tahun sama dengan Sekolah Dasar, Madrasah Tsanawiyah (MTs) sama dengan Sekolah Menengah Pertama (SMP) dengan lama belajar tiga tahun dan Madrasah Aliyah baik negeri atau swasta sama dengan Sekolah Menengah Atas (SMA) dengan tiga tahun lama belajar.

Ditinjau dari segi dinamika dan perkembangannya madrasah di Indonesia setelah merdeka terbagi tiga fase yaitu :

1. Sekitar tahun 1945-1974, madrasah menekankan materi pendidikannya kepada ilmu agama dan sedikit ilmu umum. Pada masa ini, madrasah hanya berada di lingkungan Departemen Agama Republik Indonesia.

2. Tahun 1975-1990 dengan pemberlakuan Surat Keputusan Bersama (SKB) tiga menteri yang intinya untuk meningkatkan mutu madrasah. Di antara isi Surat Keputusan Bersama (SKB) ini adalah ijazah madrasah sama nilainya dengan ijazah sekolah umum, lulusan madrasah dapat melanjutkannya pendidikannya ke sekolah umum setingkat lebih tinggi, dan siswa madrasah dapat pindah ke sekolah umum yang setingkat. Dengan dilaksanakannya SKB tiga menteri tersebut, maka eksistensi madrasah sebagai lembaga pendidikan Islam lebih mantap dan lebih kuat, pengetahuan umum pada madrasah lebih meningkat, fasilitas 
fisik dan peralatan lebih disempurnakan dan adanya civil effect terhadap ijazah madrasah.

Pemberlakuan Undang-Undang N0 2 Tahun 1989 tentang Sistem Pendidikan Nasional yang menyebutkan bahwa madrasah adalah sekolah yang berciri khas agama Islam. Dengan demikian, kurikulumnya adalah kurikulum sekolah di tambah dengan kurikulum ilmu agama sebagai ciri khasnya. ${ }^{11}$ Pendidikan Islam dilaksanakan untuk menghasilkan keterampilan yang berbasis kompetensi-kompetensi tertentu. ${ }^{12}$ Pada fase ini, pendidikan Islam berpadu dengan pendidikan umum dengan menitikberatkan kepada aspek pengembangan peserta didik, antara lain: Kognitif, Afektif, Psikomotorik. ${ }^{13}$ Pendidikan Islam dikembangkan sesuai dengan kebutuhan di tingkat sekolah masing-masing ${ }^{14}$ Selanjutnya, menghadapi tantangan masyarakat yang majemuk dan kompleks dengan latar belakang budaya yang berbeda, pendidikan Islam juga memperhatikan keberagaman tersebut dengan menyelenggarakan pendidikan yang berbasis kultur. ${ }^{15}$ Pada perkembangannya di masa sekarang, pendidikan Islam juga sangat mengedepankan pendidikan karakter. ${ }^{16}$

\section{Madrasah di Malaysia}

Malaysia adalah sebuah negara yang multikultural baik ditinjau dari segi agama, ras dan suku. Di tinjau dari segi agama penduduk Malaysia menganut agama Islam, Kristen, Katolik, Hindu, Budha

${ }^{11}$ Haidar Putra Dauly,. Dinamika Pendidikan Islam di Asia Tenggara, (Jakarta : Rineka Cipta. 2009).

12 Darmawati \& Parno, "Analisis pengembangan kurikulum berbasis kompetensi (studi kurikulum program studi muamalah jurusan syariah dan ekonomi Islam STAIN Samarinda”. dalam Jurnal FENOMENA Vol 5 No 2, 2013

${ }^{13}$ Hamzah, Syeh Hawib. "Aspek Pengembangan Peserta Didik: Kognitif, Afektif, Psikomotorik". dalam Jurnal Dinamika Ilmu, Vol. 12 No. 1, 2012

${ }^{14}$ Mukhamad Ilyasin, "Kurikulum Tingkat Satuan Pendidikan dan Urgensinya dalam Implementasi otonomi Sekolah", dalam Jurnal Dinamika Ilmu, Vol. 6 No. 1, 2006

${ }^{15}$ Fachrul Ghazi, "Pendidikan Multikulturalisme". dalam Jurnal FENOMENA Vol 4 No.2, 2012

${ }^{16}$ Agus Setiawan, "Prinsip Pendidikan Karakter Dalam Islam: Studi Komparasi Pemikiran Al-Ghazali dan Burhanuddin Al-Zarnuji", dalam Jurnal Dinamika Ilmu, Vol 14 No 1, 2014 
dan Konghuchu. Sementara jika dilihat dari segi suku, Malaysia dihuni oleh Melayu, China, India dan lain-lain. Mengingat masyarakat malaysia mayoritas penduduknya beragama Islam, maka agama Islam dijadikan sebagai agama persekutuan, meskipun agama-agama lain diamalkan oleh para penganutnya dengan aman dan damai.

Pendidikan Agama Islam diajarkan oleh institusi yang mengajarkan pendidikan agama baik sebagai ilmu (knowledge) dengan sasarannya adalah kognitif maupun sebagai nilai (value) dengan sasarannya adalah sikap dan perilaku efektif. Dengan demikian, Malaysia menggunakan beberapa lembaga pendidikan Islam sebagai institusi yang mengajarkan agama Islam. Di antara institusi yang dimaksud adalah Sekolah Rendah Enam Tahun, Sekolah Menengah, Pondok dan Pendidikan Tinggi Islam Kebangsaan.

Meskipun Malaysia tidak menggunakan istilah madrasah, akan tetapi jika dibandingkan kurikulum madrasah di Indonesia, Nigeria, Pakistan, Bangladesh, dan beberapa negara lainnya, tanpaknya penggunaan term sekolah memiliki kesamaan term madrasah. Hal ini dapat dilihat dari beberapa hal yaitu;

a. Pada level sekolah rendah, penekanan kompetensi yang harus dimiliki peserta didiknya adalah Alquran dan Jawi, pengajaran ibadah, aqidah, sirah nabi, dan praktik amal. Salah satu sekolah rendah yang memiliki kurikulum yang sama dengan madrasah ibtidaiyah di Indonesia adalah Sekolah Rendah Islam. Kurikulum sekolah ini mengikuti kurikulum yang diprogramkan pemerintah sehingga para siswa mengikuti ujian penilaian sekolah rendah, sekaligus memberikan pengajaran keagamaan.

b. Sekolah level menengah yang memiliki kurikulum yang sama dengan madrasah diantarannya adalah Sekolah Menengah Kebangsaan Agama (SMKA), Sekolah Menengah Agama Negeri dan Sekolah Menengah Agama Rakyat. Sekolah Menengah Kebangsaan Agama (SMKA) memadukan pelajaran agama seperti tafsir, hadis, fiqh, tauhid, bahasa Arab dan lain-lain dengan pelajaran umum seperti matematika, biologi, fisika, bahasa Inggris dan lain-lain. Sementara Sekolah Menengah Agama Negeri dan Sekolah Menengah Agama Rakyat memiliki kurikulum yang hampir sama dengan Sekolah Menengah kebang- 
saan Agama. Perbedaannya adalah pendidikan agamanya merujuk pada sekolah menengah agama Mesir dan penekanannya pada penguasaan bahasa Arab. ${ }^{17}$

Dari penjelasan di atas, dipahami bahwa pendidikan Islam di Malaysia seperti halnya di beberapa negara lainya. Pada awalnya pendidikan Islam hanya diberikan di sekolah-sekolah swasta, dalam perkembangannya telah menjadi bagian integral dari pendidikan nasionalnya. Dengan kata lain, pendidikan agama Islam baik berupa mata pelajaran maupun lembaga atau institusi telah menjadi bagian tak terpisahkan dari sistem pendidikan Malaysia.

Di Malaysia, setelah pendidikan agama menjadi bagian dalam sistem pendidikan nasional, maka kurikulumnya harus mengikuti kebijakan pendidikan nasional. Kurikulum madrasah di Malaysia menghendaki mata pelajarannya didasarkan pada ilmu-ilmu naqli dan aqli dengan sebutan kurikulum integrasi. Paradigma yang dibagun adalah paradigma konstruktivistik yang mengembangkan pontensi induvidu secara holistic dengan materi terintegrasi untuk menghasilkan peserta didik yang memiliki kecerdasan intelektual, spiritual, emosi dan fisik secara seimbang dan harmonis yang didasarkan pada keyakinan dan ketaatan kepada Tuhan. ${ }^{18}$

\section{Madrasah di Thailand}

Thailand adalah salah satu dari negara Asia Tenggara yang apabila ditinjau dari sudut agama yang dianut penduduknya, negara ini mayoritas penduduknya beragama Budha. Umat Islam adalah penduduk minoritas dari jumlah penduduk di Thailand. Mayoritas umat Islam di Thailand tinggal di wilayah Selatan Thailand yaitu daerah yang disebut dengan Pattani yang meliputi propinsi Yala, Narathiwat, Setul, Pattani, dan Sebagian Senggora. Jumlah penduduk wilayah ini mencapai lima juta jiwa orang atau $8 \%$ dari jumlah penduduk Thailand yang berjumlah kurang lebih 65 Juta jiwa. Delapan lima persen (85\%) dari lima juta (5.000.000) jiwa tersebut adalah memeluk agama Islam. Dengan jumlah penduduk yang jumlah mayoritas beragama Islam di wilayah bagian Selatan Thailand, maka di wilayah ini terdapat beberapa lembaga pendidikan Islam,

\footnotetext{
${ }^{17}$ Haidar (2009 : 64-69).

${ }^{18}$ http://hikmahmedia.net/index. 26 April 2009.
} 
di antaranya adalah pondok, madrasah, sekolah dan Pendidikan Tinggi Islam.

Anthony D. Medrano menyatakan bahwa secara umum ada tiga jenis institusi pendidikan Islam di Thailand yaitu : a) tipe sekolah yang memberikan pengajaran Islam tetapi menjadi bagian dari kurikulum nasional. Bahasa pembelajaran yang digunakan adalah bahasa Thai. b) tipe kedua adalah sekolah Islam swasta yang biasa disebut dengan madrasah yang mengajarkan mata pelajaran Alquran dan umum seperti sain, matematika, bahasa Asing (bahasa Arab dan bahasa Inggris). c) tipe ketiga adalah pondok. Sekolah ini sangat sederhana dalam strukturnya. Pembelajarannya secara umum berlangsung di masjid yang dilengkapi dengan tempat siswa. Disebut pondok karena para siswa yang tinggal dalam asrama sambil menuntut ilmu pengetahuan. Bahasa yang digunakan adalah bahasa Malay. Pengajaran Malay dan Jawi merupakan warisan kebudayaan penting di Thailand Selatan. ${ }^{19}$

Institusi madrasah di Thailand terbagi menjadi tiga tingkatan yaitu ibtidaiyah, mutawassitha dan tsanawiyah. Di antara madrasah terkenal di daerah ini adalah madrasah al-Rahmaniyah Fatani. Madrasah ini menggabungkan pelajaran agama dan pelajaran umum. Pelajaran umum mengikuti kurikulum pemerintah, sementara pelajaran agama disusun sendiri oleh madrasah seperti pengajian Islam, bahasa Melayu, Aqidah-Syariah, Alquran dan lain-lain. Secara Khusus ciri khas madrasah di Thailand adalah; a) sistem klassikal dengan jenjang pendidikan yang sesuai dengan tingkatan yang ditetapkan, b) memiliki kurikulum dan silabus, b) memiliki tenaga pengajar yang dalam mata pelajaran tertentu, c) mengajarkan pelajaran agama dan umum secara seimbang, d) memiliki tenaga administrasi yang menjalankan administrasi pembelajaran, e) menggunakan system management terbuka dan f) memiliki sarana dan fasilitas pembelajaran yang lengkap seperti lab bahasa, laboratorium komputer, alat olah raga dan lain-lain. ${ }^{20}$

\section{Madrasah di Nigeria Selatan}

Ada dua kelompok sekolah di Nigeria Selatan yaitu the old Islamic school dan the new Islamic schools.

\footnotetext{
${ }^{19}$ Medrano, (2007: 4)

${ }^{20}$ Haidar Putra Dauly, Dinamika Pendidikan Islam ..., hlm. 150-152
} 
Pertama, The old Islamic school terbagi dua model yaitu model the kuranic school mengajarkan tulisan Arab dan Alquran bagi anak-anak hingga remaja dan Ilm school merupakan jenjang lanjutan bertujuan mengajarkan keterampilan khusus berbagai materi keislaman. Kedua model sekolah ini menggunakan open-ended structure yang membolehkan setiap peserta didik untuk mengikuti pembelajaran secara induvidul. Ciri khusus sekolah model ini adalah; a) cenderung tidak jelas pembagian antara level dasar, menengah dan atas. b) cenderung tidak menggunakan sistem ujian untuk perkembangan dari satu kelas ke kelas berikutnya. c) tidak ada ketetapan batas umur dan kejelasan waktu untuk menempuh satu level. d) materi ajaranya adalah keterampilan dasar calistung. Model sekolah ini cenderung gagal memberikan keterampilan dan pengetahuan bagi peserta didik untuk bekerja dalam masyarakat. Inilah yang menjadi salah satu penyebab lahirnya sekolah Islam untuk memperbaiki standar sekolah quran dengan mengadopsi sistem sekolah formal.

Kedua, New islamic schools yang mengadopsi sistem sekolah modern bercirikan; a) lingkungan sekolah dibiasakan dengan suasana keislaman; b) administrator secara aktif memelihara identitas Islam dan kesadaran di antara siswa dan guru tidak hanya dalam kelas tetapi juga dalam berbagai aktifitas sekolah; c) shalat jama'ah selalu dilaksanakan; d) pakaian yang berciri khas keislaman dibiasakan; e) kurikulumnya menekankan pada studi Arab dan Islam dengan dua tipe yaitu; a) school operating madrasah curriculum.Tujuan kurikulumnya adalah melahirkan ilmuan yang dapat memahami materi sekuler modern dengan $70 \%$ pendidikan Islam atau Arab dan sebesar 30\% pendidikan sekuler. b) Sekolah yang menyelenggarakan kurikulum nasional yang dimodifikasi dengan sekolah umum. Model kurikulumnya mengadopsi $70 \%$ sistem pendidikan Barat dan $30 \%$ pendidikan keislaman/Arab. ${ }^{21}$

Sebuah hasil penelitian menunjukkan bahwa madrasah atau sekolah Islam di Nigeria memiliki jumlah siswa yang banyak, namun ruang kelas yang sempit sehingga menghalangi pelaksananan pembelajaran yang menggunakan pendekatan yang terpusat pada 
siswa, rata-rata guru telah menggunakan pembelajaran yang terpusat pada siswa meskipun di antara mereka masih ada yang tetap menggunakan metode pembelajaran tradisional. ${ }^{22}$

\section{Madrasah di Flipina}

Penduduk yang beragama Islam di Filipina terkonsentrasi di bagian Selatan terutama di Mendanau, ujung selatan Palawani dan gugusan kepulauan Sulu. Mereka terdiri dari tiga belas kelompok bahasa dan budaya yaitu Maranao, Iranum, Maguindanau, Tausugs Samal, Bajao, Jama Mapun, Molbog, Kalibugan, Yakan, Karasa, dan Sangil.

Lembaga pendidikan Islam berupa madrasah pertama didirikan oleh Sultan Syariful Hasyim Abu Bakar. Jika dilihat dari perkembangan madrasah hingga saat ini, maka ada dua tiga jenis madrasah di Filipina Selatan. Ketiga jenis madrasah yang dimaksud adalah; a) Madrasah Diniyah Sabtu-Minggu. Madrasah ditujukan bagi siswa yang bersekolah umum di pagi hari. Mata pelajaran yang diajarkan adalah Alquran, hadis, tauhid, fiqh, sirah, qawaidullughah, tajwid, imra dan qira'ah. b) Madrasah Diniyah Reguler lima hari seminggu. Madrasah ini mengasuh taman kanak-kanak dua tahun, ibtidaiyah enam tahun, mutawasithah tiga tahun dan tsanawiyah tiga tahun. Mata pelajaran yang diajarkan adalah mata pelajaran agama yang bersumber dari kitab seperti tafsir, nahwu, tauhid, hadis, tafsir ibnu katsir, subulussalam, matan al-jurmiyah dan lain-lain. c) Madrasah Integrasi. Madrasah ini merupakan hasil pembaruan dengan mengembangakan dua jenis pendidikan yaitu agama dan umum. $^{23}$

Pemerintah Filipina juga melakukan sebuah upaya untuk mengakomodasi aspirasi masyarakatnya yang beragama Islam dengan berbagai program. Salah satu di antaranya adalah pengiriman guru dan tenaga administrasi dalam satu tahun selama tiga minggu ke Amerika Serikat pada tahun 2005. Program ini berakhir pada bulan Desemeber 2007. Dalam program tersebut, kelompok guru tersebut diperkenalkan berbagai hal tentang Amerika Serikat di antaranya: landasan pendidikan Amerika, pembelajaran partisipatory, persi-

${ }^{22}$ El-Khalik...,2006. hlm. 6-14

${ }^{23}$ Haidar Putra Dauly, Dinamika Pendidikan Islam ..., hlm. 170-172 
apan siswa menjadi warga negara yang baik, pengembangan kurikulum integrasi, pendidikan nilai, pengaturan perioritas untuk program sekolah, managemen keuangan sekolah, pengembangan sumber daya manusia dan lain-lain.

Program ini didasarkan pada keinginan pemerintah Filipina untuk mengembangkan bangsa Moro melalui sebuah program yang dikenal dengan "pendidikan untuk perdamaian dan pengembangan kota Mindanau". Tujuan utama dari program ini adalah mengintegrasikan madrasah ke dalam sistem pendidikan nasional, membantu menciptakan pemahaman guru antara minoritas muslim dengan kelompok mayoritas Kristen. Lima hal penting dari program ini adalah; teknologi informasi dan komunikasi, pendidikan madrasah, pendidikan perdamaian, sejarah dan budaya masyarakat Mindanau dan pelatihan guru madrasah. ${ }^{24}$

\section{Madrasah di Singapura}

Madrasah di Singapura sesungguhnya memiliki jumlah yang cukup banyak. Hingga saat ini hanya tinggal enam madrasah yang berfungsi dengan baik sebagai lembaga pendidikan Islam. Keenam madrasah yang dimaksud adalah madrasah al-sagaf (19920, madrasah al-arabiyah (1925), madrasah al-junaid (1927), madrasah al-ma'arif (1936), madrasah al-Irsyad (1947) dan madrasah wak tanjung (1955). ${ }^{25}$

Pada dasarnya madrasah di Singapura bertujuan untuk melahirkan sarjana agama dan professional muslim. Perjuangan untuk menyeimbangkan tujuan pendidikan yang bercorak sekuler dan pendidikan yang bercorak spiritual atau religius tersebut adalah tema sentral.

Salah satu hal yang menarik tentang madrasah di Singapura adalah adanya "madrasah Separuh Masa". Madrasah ini melangsungkan pembelajarannya tidak tiap hari, tetapi mungkin dua atau tiga kali dalam seminggu dan dilaksanakan pada sore atau malam hari. Materi yang diajarkan lebih menekanakan pendidikan agama, Di antara kegiatan madrasah separuh masa ini adalah kursus iqra, mengaji, muqaddam, bacaan dan tulisan jawi, talaqqi Alquran dan

${ }^{24}$ Joy Gloria P. Sabutan, Strengthening Islamic Education in Southen

Phillippines : an Evaluation of the Phillippine Madrasah Program. Graduate School, University of Southen Mindanau, 2008 ), hlm.: 1-6

${ }^{25}$ Haidar Putra Dauly, Dinamika Pendidikan Islam ..., 2008.hlm. 119 
bimbingan Akhlak. Oleh karena itu, banyak kalangan yang menganggap madrasah ini layak disebut pendidikan informal.

Dalam perkembangannya madrasah di Singapura, dilakukan pembaharuan dalam sistem pendidikannya dengan mengadopsi pendekatan konservatif yang menekankan pada pendidikan keagamaan bukan pengetahuan sekuler, meskipun pendidikan umum tidak ditinggalkan sama sekali. Madrasah al-Junaid misalnya telah melakukan pengembangan kurikulum dengan mengajarkan pendidikan umum 30\% dan pendidikan agama $70 \%$.

Perkembangan madrasah di Singapura tidak seperti perkembangan madrasah di Negara lain, khususnya di Asia Tenggara. Hal ini terlihat dari adanya beberapa kritikan terhadap eksistensi madrasah. Di antara kritikan yang dimaksud adalah; a) kurikulum dan mata pelajaran madrasah semestinya disamakan dengan sekolah nasional lainnya, b) menilai secara kritis pendidikan madrasah dengan mengevaluasi tujuan, isi dan pendekatan paedagogiknya, c) madrasah di Singapura bukan sekolah nasional dan siswa madrasah dibebaskan dari ujian akhir, meskipun mereka juga diberikan standar minimal dari pemerintah. Sebenarnya dengan pembelajaran akademik dan agama serta pemberian waktu kurikulum yang sama, sesungguhnya madrasah bisa mencapai penampilan terbaik di Singapura. d) perdebatan seputar persepsi tentang pengetahuan oleh pemerintah singapura dan masyarakat muslim. Pemerintah menganggap bahwa pengetahuan adalah keterampilan teknik dan keahlian, sementara masyarakat muslim menganggapnya sebagai hubungan manusia dengan kepatuhan dan ketuhanan dan e) kontribusi filsafat progressive dalam pendidikan Islam dan mendorong agar madrasah dinilai dan diperbaiki atas dasar filsafat dan nilai-nilai ini. ${ }^{26}$

\section{Madrasah Bangladesh}

Ada dua jenis madrasah di Bangladesh yaitu madrasah Quami (Quomi Madrassas) yang diperkirakan jumlahnya mencapai lebih dari 6,500 madrasah yang terdiri dari tingkat dasar, menengah dan

${ }^{26}$ Tan, Charlene.. "Islam and Citizenship Education in Singapore : Challenges and Implications" dalam Journal Education, Citizenship and Social Justice. 2007. hlm.3-5 http://esj.sagepub.com/cgi/content/abstract/2/1/23, diakses, 29 Maret 2015 
atas. Sementara jumlah siswa diperkirakan mencapai $1,462,500$ siswa dan 130,000 Guru. Madrasah ini sesungguhnya tidak memperoleh bantuan dari pemerintah, akan tetapi madrasah ini didukung oleh pengusaha dan hartawan yang religious berupa bantuan zakat dan donasi. Dengan donasi yang bersifat outonomi ini, maka madrasah ini merupakan sumber utama kekuatan politik agama yang bersifat independen yang mendasarkan diri pada ulama di Bangladesh.

Kategori lain sistem madrasah di Bangladesh adalah madrasahmadarasah yang dikontrol oleh pemerintah Bangladesh. Kurikulum yang dikembangkan bercorak religious dan sekuler. Ada lima tingkatan bagi jenis madrasah yang dikontrol oleh pemerintah yaitu a) ibtedai (elementary), b) dakhil (secondary), c) alim (higher secondary), d) fazil (B.A.), e) kamil (M.A.). Seluruh tingkatan madrasah ini mengajarkan mata pelajaran modern seperti bahasa Inggris, Bangla, Sain, Studi sosial, matematika, geografi, sejarah dan lainlain. ${ }^{27}$

Seperti halnya negara-negara tersebut di atas, Bangladesh mengembangkan ciri khas madrasah yang dilakukan dengan berbagai cara di antaranya adalah menggunakan bahasa Urdu sebagai pengantar pembelajaran, Bangla ditetapkan sebagai subjek wajib untuk level menengah, mata pelajaran politik, ekonomi dan sejarah Islam diajarkan, bahasa Inggris adalah mata pelajaran wajib, Sekolah Dasar diintegrasikan ke dalam madrasah Quomi yang mengajarkan pendidikan umum dan agama, perbandingan agama ditambahkan dalam kurikulum, birokrasi dan prosedur administrasi serta management professional, adanya standarisasi evaluasi akademik oleh institusi dengan system sentralisasi kurikulum, silabi dan ujian dan bantuan dapat diperoleh dari berbagai sumber. ${ }^{28}$

\section{Madrasah di Pakistan}

Madrasah di Pakistan memiliki beberapa kategori jika dilihat dari sisi tingkatannya. Kategori yang dimaksud adalah 1) madrasah ibtidaiyah (ibtedai elementary). Materi yang diajarkan adalah hafal Alquran. 2) madrasah vustani pada tingkat menengah dimana bukubuku atau kitab yang diajarkan adalah buku yang diseleksi dari Dars-i-Nizami. 3) madrasah fauquani sebagai level atas yang tidak

\footnotetext{
${ }^{27}$ Mumtaz ....hlm. 5

${ }^{28}$ Mumtaz ..., hlm. 11-12
} 
hanya mengajarkan pendidikan agama tetapi juga mata pelajaran umum.

Berbicara tentang madrasah di Pakistan, banyak anggapan yang mengkaitakan antara madrasah dengan serangan 11 september di USA pada tahun 2001. Oleh karena itu, upaya pemerintah Pakistan untuk mereformasi sistem madrasah tentu bertujuan merubah persepsi dunia saat ini tentang militan Pakistan. Reformasi dilakukan dengan cara: a) seluruh madrasah harus terdaftar di dewan madrasah propinsi. b) melarang madrasah menerima bantuan terutama dari luar negeri. c) kurikulum dikembangkan dengan corak modern yang mengajarkan pengetahuan umum, d) madrasah dimasukkan sebagai bagian dari system integrasi pendidikan nasional dengan modernisasi kurikulum dan peningkatan kesejahteraan pelaku pendidikanya. ${ }^{29}$

\section{Pengembangan Madrasah Menjadi Institusi Pendidikan Islam "Unggul"}

\section{Proses Pengembangan Kurikulum Madrasah Unggul}

Salah satu upaya menjadikan madrasah unggul adalah dengan melakukan pengembangan kurikulum berbasis sekolah/madrasah. Pengembangan kurikulum berbasis sekolah/madrasah dapat didefinisikan sebagai upaya pengembangan kurikulum dengan menggunakan pendekatan botton up or school based Curriculum yang memberi peluang secara utuh kepada sekolah/madrasah untuk melakukan pengembangan kurikulum.

Pengembangan Kurikulum Berbasis Sekolah/Madrasah atau School Based Curriculum Development memiliki ciri di antaranya;

1) Dalam proses pengembangan kurikulum, para guru dilibatkan dalam bentuk partisipasi mereka dalam pengambilan keputusan yang berkaitan dengan pengembangan dan pelaksanaan kurikulum madrasah

2) Melibatkan seluruh komponen sekolah/madrasah yang meliputi kepala sekolah, guru, staff, masyarakat, siswa dan lain-lain

3) Pengembangan kurikulum bersifat selektif, adaptif dan kreatif.

4) Adanya pergeseran tanggungjawab pengambilan keputusan kurikulum dengan tidak memutuskan garis hubungan sekolah dengan pusat.

${ }^{29}$ Leony, Robert. (2003 : 1-12). 
5) Bersifat terus menerus dan dinamis yang secara ideal melibatkan guru,tenaga kependidikan lainnya, masyarakat, orang tua dan siswa.

6) Melibatkan kebutuhan dukungan struktur yang bervariasi

7) Adanya sebuah perubahan peran guru yang bersifat tradisional yang hanya bertugas sebagai pengajar menjadi peneliti dan pengembang kurikulum. ${ }^{30}$

\section{Melibatkan berbagai Personil dalam pengembangan kurikulum "Madrasah Unggul"}

Secara history ada empat macam personil yang berbeda yang terlibat dalam pengambilan keputusan kurikulum termasuk dalam hal ini pengembangan kurikulum berbasis sekolah/madrasah sebagai berikut: "Specialized personnel, representative groups composed of specialized personnel and class room teacher, all profesional personnel and all professional personnel plus representative lay citizens and student". Keempat personil yang dimaksud adalah sebagai berikut;

1. Specialized personnel. Personil-personil ini adalah a) mereka yang berasal dari sekolah seperti guru dan supervisor. b) ahli bidang studi atau mereka yang terlatih dalam penelitian organisasi kurikulum.

2. Representative groups composed of specialized personnel and class room teacher adalah gabungan dari guru kelas madrasah dan grup perwakilan dari para ahli bidang kurikulum madrasah

3. All profesional personnel adalah seluruh guru kelas, supervisor, guru khusus dan administrator. Mereka inilah yang berpartipasi dalam tiga system yaitu kurikulum, pembelajaran dan evaluasi.

4. All professional personnel plus representative lay citizens and student adalah mereka yang tersebut pada nomor tiga ditambah dengan warga masyarakat yang konsen terhadap sekolah. Walaupun ada yang mempertanyakan keterlibatan masyarakat dalam rekayasa kurikulum dengan alasan bahwa rekayasa kurikulum itu bersifat teknis. Para pendukung beranggapan perlunya partnership dalam dunia pendidikan, sehingga tugas dari para masyarakat adalah melakukan pertimbangan nilai. ${ }^{31}$

\footnotetext{
${ }^{30}$ Laurie Broudy ..., 1990.hlm. 8

${ }^{31}$ Beauchanb ...,1975. hlm. 169-172
} 


\section{Mengembangkan Model Kurikulum "Integrasi"}

Untuk mengembangkan madrasah menjadi lembaga pendidikan Islam unggul yang mampu bersaing dengan lembaga pendidikan formal lainnya di berbagai belahan dunia ini, maka semestinya madrasah di berbagai negara muslim khususnya, mengembangkan model kurikulum integratif. Hal ini penting untuk mencetak generasi muslim yang tidak hanya memiliki kecerdasan otak (head) tetapi juga memiliki berbagai kecerdasan yang lainnya seperti kecerdasan emosi (heart), kecerdasan kreatif (hand) dan keceradasan spritual (honest). Model kurikulum berikut ini berangkali merupakan salah model kurikulum integratif yang mungkin dikembangkan untuk melahirkan berbagai keterampilan dan kecerdasan bagi para siswa dan alumninya.

Model Kurikulum Madrasah Unggul (sebuah alternatif)

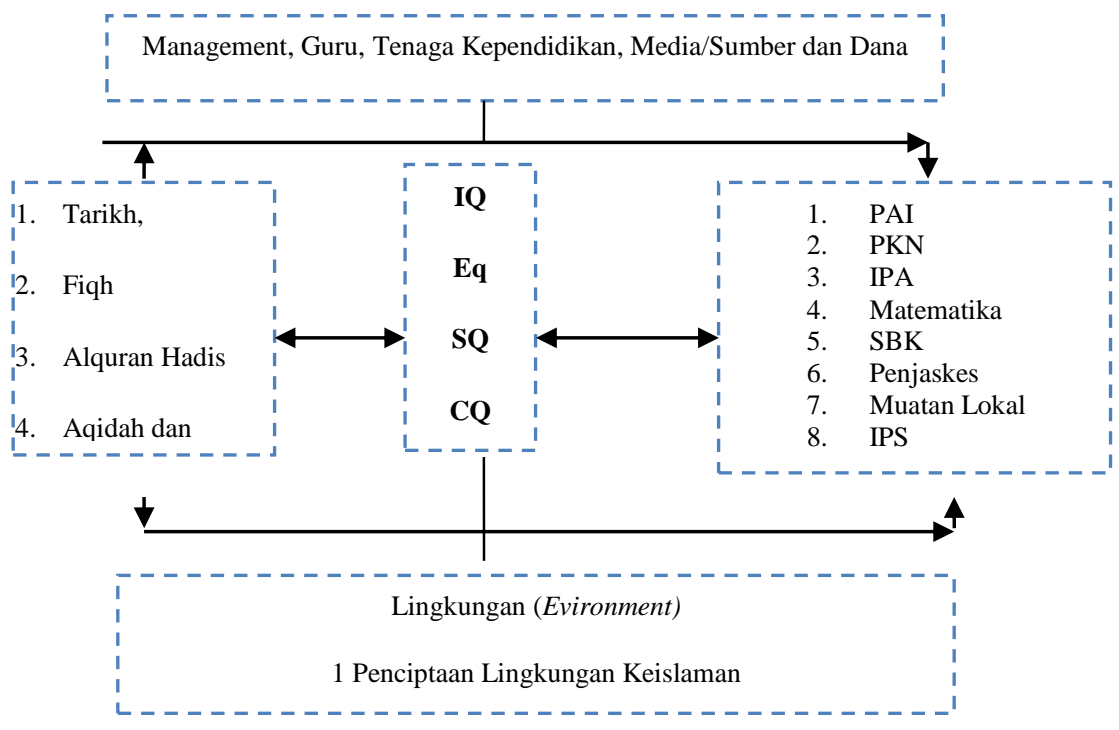

Beberapa negara di Asia, pada dasarnya telah mengembangkan model kurikulum integrasi seperti tergambar di atas. Misalnya di Indonesia, upaya untuk menggabungkan antara ilmu-ilmu kewahyuan dan dan bukan wahyu telah dilaksanakan pada awal abad keduapuluh setelah kembalinya para pelajar Indonesia dari Timur Tengah. Gaung penyatuan ilmu perennial knowledge dan acquired knowledge terdengar sangat menggema ketika dilaksnakan konferensi pertama pendidikan Islam sedunia pada tahun 1975. 
Sementara di Malaysia, konsep integrasi keilmuan telah dilaksanakan mulai tingkat sekolah rendah. Sementara Integrasi keilmuan pada tingkat menengah dilakukan di Sekolah Menengah Agama Negeri (SMAN), Sekolah Menengah Agama Kebangsaan (SMAK) dan Sekolah Menengah Agama Rakyat (SMAR). Demikian halnya di Brunai Darussalam, Singapura, Filipina, Thailand, Bangladesh, Pakistan, Nigeria dan lain-lain. ${ }^{32}$

\section{Pengembangan Unsur-Unsur Sistem Madrasah Lainnya.}

Pengembangan madrasah harus didekati dengan dua pendekatan yaitu pendekatan macrospic (tinjauan makro) dengan melakukan analisa yang berkaitan dengan kerangka sosial yang lebih luas, dan pendekatan mikrospic (tinjauan mikro) dengan melihat madrasah sebagai suatu kesatuan unit yang hidup dan terdapat saling interaksi di dalam dirinya sendiri. Kedua pendekatan tersebut di atas bersifat saling melengkapi, terutama ditengah-tengah masyarakat yang semakin terbuka dan kompleks yang melahirkan interaksi dengan berbagai aspek kehidupan seperti saat ini. Untuk itu, diperlukan adanya keterbukaan wawasan dan keberanian dalam memecahkan masalah-masalahnya secara mendasar dan menyeluruh.

Upaya-upaya pengembangan madrasah harus selalu mengakomodasikan tiga kepentingan utama, yaitu, a) sebagai wahana untuk membina ruh atau praktek hidup keislaman, b) memperjelas dan memperkokoh keberadaan madrasah sederajat dengan sistem sekolah, sebagai wahana pembinaan warga negara yang cerdas, berpengetahuan, berkepribadian dan produktif, dan c) mampu merespon tuntutan-tuntutan masa depan, dalam arti sanggup melahirkan manusia yang memiliki kesiapan memasuki era globalisasi, industrialisasi maupun era informasi.

Mastuhu secara praktis memberikan konsep tentang model dan paradigma pendidikan Islam, yaitu; a) dasar pendidikan ; pendidikan Islam harus mendasarkan pada "teosentris" dengan menjadikan "antroposentris" sebagai bagian esensial dari konsep teosentris. Hal ini berbeda dengan pendidikan sekuler yang hanya bersifat antroposentris semata, b) tujuan pendidikan ; kerja membangun kehidupan duniawiyah melalui pendidikan sebagai perwujudan mengabdi kepada-Nya. c) konsep manusia, pendidikan Islam memandang manusia mempunyai fitrah yang harus dikembangkan,

\footnotetext{
${ }^{32}$ Haidar Putra Dauly, Dinamika Pendidikan Islam ..., hlm.191-206.
} 
tidak seperti pendidikan sekuler yang memandang manusia dengan tabularasa-nya, d) nilai, pendidikan Islam berorientasi pada Iptek sebagai kebenaran relatif dan Imtaq sebagai kebenaran mutlak. Berbeda dengan pendidikan sekuler yang hanya berorientasi pada Iptek.

\section{Penutup}

Sistem madrasah di berbagai negara, terutama di Asia pada umumnya memiliki kesamaan dalam proses perkembangannya. $\mathrm{Pa}-$ da mulanya madrasah hanya merupakan lembaga pendidikan Islam yang hanya mengajarkan mata pelajaran agama. Dalam perkembangannya, madrasah diberbagai negara telah melakukan prosses intergrasi dengan mengajarkan mata pelajaran agama dan mata pelajaran umum. Hal tersebut dilakukan untuk mengakomodasi perkembangan zaman yang semakin maju.

Selain integrasi mata pelajaran yang diajarkan madrasah, pengembangan unsur-unsur system madrasah lainnya juga memerlukan perhatian yang serius. Ada dua unsur sistem madrasah yang perlu mendapat perhatian yaitu unsur organic berupa para pelaku madrasah yang meliputi kepala madrasah, guru atau pendidik, murid atau siswa dan pengurus, dan unsur-unsur non organic yang meliputi tujuan pendidikan, filsafat dan tata nilai, dan seumber belajar, proses kegiatan belajar mengajar, dana, dan sarana, evaluasi dan peraturan lain yang terkait di dalam pengelolaan madrasah

\section{Kepustakaan}

Abdullah, Amin. 1998. Problem epistemologis metodologis Pendidikan Islam, dalam Religius Iptek, Yogyakarta : Pustaka Pelajar.

Abusyairi, Khairy. 2013. Pembelajaran Bahasa dengan Pendekatan Budaya. Dinamika Ilmu. Vol. 13 No 2, 2013

Al-Nahlawi, Abdurrahman. 1996, Pendidikan Islam di Rumah, Sekolah dan Masyarakat, diterjemahkan oleh Shihabuddin dari jjudul aslinya Ushul al Tarbiyah al-Islamiyah wa Asalibihu fi al-Bayt wa al-Madrasah wa al Mujetama. Cet.II. Jakarta : Gema Insani Press.

Andaryuni, Lilik. 2014. Pendidikan Multikultural Di Perguruan Tinggi. FENOMENA Vol 6 No 1, 2014 
Darmawati \& Parno. 2013. Analisis pengembangan kurikulum berbasis kompetensi (studi kurikulum program studi muamalah jurusan syariah dan ekonomi islam STAIN Samarinda). FENOMENA Vol 5 No 2, 2013

Dauly, Haidar Putra. 2009. Dinamika Pendidikan Islam di Asia Tenggara, Jakarta: Rineka Cipta.

Fouad Abd-El-Khalick, Et.ell. 2006. Educational Quality in Islamic School in Negria. American Institutes for Research under the EQUIP1 LWA with Education Develompment Center. http://www.equip123.net/docs/E1-NigeriaPilotStudy.pdf, diakses, 24 April 2015

Ghazi, Fachrul. dkk. 2012. Pendidikan Multikulturalisme. FENOMENA Vol 4 No.2, 2012

Gloria P. Sabutan, Joy. 2008. Strengthening Islamic Education in Southen Phillippines : an Evaluation of the Phillippine Madrasah Program. Graduate School, University of Southen Mindanau.

Haidar dan Fauzan. 2005. Sejarah Sosial Pendidikan Islam. Jakarta : Kencana.

Hamzah, Syeh Hawib. 2012. Aspek Pengembangan Peserta Didik: Kognitif, Afektif, Psikomotorik. Dinamika Ilmu, Vol. 12 No. 1,2012

Ilyasin, Mukhamad. 2006. Kurikulum Tingkat Satuan Pendidikan dan Urgensinya dalam Implementasi otonomi Sekolah. Dinamika Ilmu, Vol. 6 No. 1, 2006

Ilyasin, Mukhamad. 2010. Pendidikan Islam dalam Pendekatan Multidisipliner: Suatu Pengantar Kajian Gradual Menuju Paradigma Global. Dinamika Ilmu. Vol. 10 No 2, 2010

Julaiha, Siti. 2014. Implementasi Pendidikan Karakter dalam Pembelajaran. Dinamika Ilmu, Vol 14 No 2, 2014

Julaiha, Siti. 2014. Internalisasi Multikulturalisme dalam Pendidikan Islam. Dinamika Ilmu, Vol 14 No 1, 2014

Langgulung, Hasan dan Nuraini Hashim, 2008, Islamic Relegion Curriculum in Muslim Countries : The Experiences of Indonesia and Malaysia. International Islamic University. Malaysia: Bulletin of Education and Research. http://hikmahmedia.net/index.php?option=com_content\&view=articl e\&id, diakses 26 April 2015 
Mahmud, M. E. \& Zamroni. 2014. Peran Masjid dalam Pengembangan Pendidikan Agama Berwawasan Multikultural pada Masyarakat. FENOMENA Vol 6 No 1, 2014

Mastuhu 1994. Dinamika Sistem Pendidikan Pesantren, , INIS, jakarta

, 1999. Memberdayakan Sistem Pendidikan Islam, Logos, Jakarta

Medrano, Anthony D., 2007. Islamic Education in Southern Thailand. University of Hawai'i at Manoa : Explorations A Graduate Student Journal Of Southeast Asian Studies. http://www.hawaii.edu/cseas/.pdf, di akses 24 April 2015.

Muhaimin, 1998. Potret Paradigma Pengembangan Pendidikan Islam di Indonesia, Malang : Jurnal STAIN Malang

Munawwir, Ahmad Warson. 1994, Kamus al-Munawwir Arab Indonesia.

Nashruddin, Wakhid. 2015. Teaching English as A Foreign Language at Madrasah Ibtidaiyyah: Facts and Challenges. Dinamika Ilmu, Vol. 15 No 1

Raharjo, Dawam. 1998. Keluar dari Kemelut Pendidikan Nasional, Malang : Jurnal STAIN Malang.

Setiawan, Agus. 2014. Prinsip Pendidikan Karakter Dalam Islam: Studi Komparasi Pemikiran Al-Ghazali dan Burhanuddin Al-Zarnuji. Dinamika Ilmu, Vol 14 No 1, 2014

Tafsir, Ahmad. 1 Ghazi, Fachrul. dkk. 2012. Pendidikan Multikulturalisme. FENOMENA Vol 4 No.2, 2012992, Ilmu Pendidikan dalam Perspektif Islam. Cet. I. Bandung : Remaja Rosdakarya.

1997 Eksistensi Madrasah sebagai sekolah Umum yang berciri khasIslam, Malang : Fakultas Tarbiyah, IAIN Malang.

Tan, Charlene. 2007. Islam and Citizenship Education in Singapore : Challenges and Implications. Journal Education, Citizenship and Social Justice. http://esj.sagepub.com/cgi/content/abstract/2/1/23, diakses, 29 Maret 2015, Yogyakarta : Pondok Pesantren al-Munawwir. 